\title{
Antibacterial activity of Solanum lycopersicum var. ceraciforme on aerobic microbial isolates of meat
}

\author{
Victor Aduloju ${ }^{1 *}$, A. T. Ezegbe ${ }^{1}$, C. C. and Aduloju ${ }^{2}$, T. A. \\ ${ }^{1}$ Department of Food Science and Technology Nnamdi Azikiwe University Awka, Anambra State. Nigeria. \\ ${ }^{2}$ Department of Applied Sciences, Federal College of Dental Technology and Therapy, Enugu, Enugu State. Nigeria. \\ yemtop2013@gmail.com
}

\begin{abstract}
The antibacterial activities of the extract of Solanum lycopersicum var. ceraciforme were evaluated against five bacteria: Serratia marcescens, Micrococcus luteus, Streptococcus pyrogenes, Pseudomonas aeruginosa and Bacillus cereus. Ethanolic extract (UEE) of Solanum lycopersicum var. ceraciforme were obtained by standard methods. The antibacterial activity was assayed using agar well diffusion method. The ethannolic extract (UEE) exhibited antibacterial effects against the isolates with inhibiting zones ranging from $2.09 \pm 0.01 \mathrm{~mm}$ to $7.53 \pm 0.01 \mathrm{~mm}$. UEE was able to inhibit the growth of Serratia marcescens and Micrococcus luteus which was resistant to the commercial antibiotic, erythromycin. The extract showed appreciable quantity of total phenol (tannic acid equivalent) of 22.12 MgGAE/g. The higher phenolic content of UEE may be responsible for its ability to inhibit more of the aerobic microflora from meat. This study shows that useful bioactives component that can be used in preserving meat from microbial spoilage are present in UEE.
\end{abstract}

Keywords: Solanum lycopersicum var. ceraciforme, antibacterial activity, extract, meat.

\section{INTRODUCTION}

Meat is animal flesh that is eaten as food (Lawrie and Ledward, 2006). Meat is mainly composed of water, protein and fat and is usually eaten together with other food. Meat is one of the most nutritious foods used for human consumption. The actual composition of meat depends however on the breed, age, sex, nutrition and state of health (Aurand et al., 1987). Shelf life and maintenance of the meat quality are influenced by a number of interrelated factors including holding temperature, which can result in detrimental changes in the quality attributes of meat. Spoilage by microbial growth is the most important factor in relation to the keeping quality of meat (Lambert et al., 1991). In most developing countries, including Nigeria, fresh meat forms a significant proportion of meat intake (Olaoye and Idowu, 2010). It is either eaten cooked or processed into other forms to avoid associated spoilage. The main causative factor of such spoilage has been linked to unavailability of necessary storage facilities and favourable ambient temperature that usually prevail in developing countries that are in tropical regions (Onilude et al., 2002). Meat has long been considered a highly desirable and nutritious food, but unfortunately it is also highly perishable because it provides the nutrients needed to support the growth of many types of microorganisms (Kalalou et al., 2004). Due to its unique biological and chemical nature, meat undergoes progressive deterioration from the time of slaughter until consumption. In general, the metabolic activity of the ephemeral microbial association which prevails in a meat ecosystem under certain aerobic conditions, or generally introduced during processing, leads to the manifestation of changes or spoilage of meat (Nychas et al., 2008).

The spoilage of meat occurs if untreated in a matter of hours or days and results in the meat becoming unappetizing, poisonous or infectious. Spoilage is caused by the practically unavoidable infection and subsequently decomposition of meat by bacteria and fungi which are 
borne by the animal itself, by the people handling the meat and by implements. Meat can be kept edible for a much longer time though not indefinitely if proper hygiene is observed during production and processing and if appropriate food safety, food preservation and food storage procedures are applied (Adams and Moss, 2000). A number of interrelated factors influence the shelf life and keeping quality of meat, specifically holding temperature, atmospheric oxygen (O2), indigenous enzymes, moisture (dehydration), light and, most importantly, micro-organisms. All of these factors, either alone or in combination, can result in detrimental changes in the colour, odour, texture and flavour of meat. Fresh meat has a shelf life of 1 day or less at ambient storage temperatures, $20-30^{\circ} \mathrm{C}$ (Lambert et al., 1991).

Spoilage is said to be a state of a particular food in which it is offensive to consumers' senses, usually caused by metabolites of contaminant microorganisms (Paulsen and Smuldens, 2003). Meat spoilage is not always evident and consumers would agree that gross discoloration, strong off-odours, and the development of slime would constitute the main qualitative criteria for meat rejection. In general, spoilage is a subjective judgment by the consumer, which may be influenced by cultural and economic considerations and background as well as by the sensory acuity of the individual and the intensity of the change (Nychas et al., 2008). Spoilage of meat can be considered as an ecological phenomenon that encompasses the changes of the available substrata, such as low molecular weight compounds, during the proliferation of bacteria that constitute the microbial association of the stored meat (Nychas et al., 2007). The microbiological quality of meat depends on the physiological status of the animal at slaughter, the spread of contamination during slaughter and processing, the temperature and other conditions of storage and distribution. In fact, some of the microorganisms originate from the animal's intestinal tract as well as from the environment with which the animal had contact at some time before or during slaughter (Koutsoumanis and Sofos, 2004).

Other organisms, including psychrotrophic bacteria, are recovered from hides and work surfaces within an abattoir as well as from carcasses and butchered meat at all stages of processing (Gill, 2005). A wide range of micro-organisms coming from different sources are introduced onto carcass surfaces, which contain abundant nutrients and which have high water availability. Only a few of the contaminants will be able to initiate growth, and only some of these will eventually spoil the meat by means of their biochemical attributes.

Predominance of different groups of microorganisms on meat depends on the characteristics of the meat, the environment in which meat is stored as well as the processing that meat may undergo (Gill and Molin, 1991). The problems of spoilage and food poisoining mainly by oxidation processes or by microorganisms activity during production and storage are still concerns for both the food industry and consumers despite the use of synthetic chemical additives and various preservation methods (Lawrie and Ledward, 2006; Adams and Moss, 2000). However, the side effects of some synthetic antioxidants used in food processing such as butylated hydroxytoluene (BHT) and butylated hydroxyanisole (BHA) have already been documented. They showed carcinogenic effects in living organisms.

Cherry tomato (Solanum lycopercicum var. cerasiforme Linn Moench) are widely consumed either raw or after processing and can provide a significant proportion of the total antioxidants in the diet (Martinez-Valvercle, 2002). It is an important source for the daily intake of healthy constituents to the diet like minerals (calcium, phosphorous, magnesium and other minor minerals), water-soluble vitamins ( $B$ and $C)$, fat-soluble vitamins $(A$, $E$ and $K$ ) and a wide variety of phytochemicals (Shahidi et al., 2008). Among phytochemicals, we can find bioactive molecules capable to protect against diseases acting as free radical scavengers or antimicrobial agents. Cherry tomato contain carotenoids, lycopene and flavonoids which have powerful antitumour and anticancer properties. Also high intake of cherry tomato prevents cancer of breast, cervix, colon, oesophagus, mouth and pancrease. The anticancer effects are best against prostrate, lung and stomach cancer (Edward, G. (1999): Ellinger et al., (2006); Aune, 2012).

Cherry tomato exhibited numerous health benefits in preventing and treating a wide variety of diseases such as aging, metabolic, neurological, cardiovascular, and inflammatory diseases. Their role in food safety and preservation have not been studied. Therefore, the present study aims to provide a comprehensive summary on the antibacterial activity of the ethanolic extract of Solanum lycopersicum var. cerasiforme on aerobic microbial isolates of meat.

\section{MATERIAL AND METHODS}

\section{Collection of samples.}

\section{Source and identification of tomato.}

Cherry tomato (Solanum lycopersicum var. cersiforme) were collected from Teaching and Research farm of the Federal University of Technology, Akure, Ondo State, Nigeria. The tomatoes were identified at the Department of Crop, Soil and Pest Management, Federal University of Technology, Akure, Ondo State. The tomatoes were washed, sliced and sun dried for two weeks and then blended into powder using Marlex mixer grinder model 7371373.

\section{Source of meat.}

The meat (Beef) was obtained from Oja Oba market 
Akure, Ondo State, Nigeria. The meat were stored in sterile container under room temperature.

\section{Preparation of extract}

Twenty grams of grounded Solanum lycopersicum var. cersiforme was extracted with ethanol. The extraction by the solvent was performed in Erlenmeyer flask shaken on an orbital shaker at $300 \mathrm{rpm}$ and at room temperature for $48 \mathrm{~h}$. The extract obtained from the extracting medium was evaporated to dryness.

\section{Isolation of microorganism from meat.}

One gram of homogenized meat was taken from the dissolved into $9 \mathrm{ml}$ of the sterilized water in the McCartney. Serial dilution of the sample was carried out to a dilution factor of $10^{5}$. Exactly $0.1 \mathrm{ml}$ aliquot of $10^{3}$ were aseptically pipette into different sterile Petri dishes. After this; the sterile molten nutrient agar were aseptically poured into each corresponding Petri dish. The plate were incubated in an inverted position. Incubation period was $37^{\circ} \mathrm{C}$ for $24 \mathrm{~h}$. Distinct bacterial

colonies formed after incubation were isolated for characterization (Fawole and Oso, 2001).

\section{Identification of bacterial species}

The identification of bacteria was based on cultural characteristics, staining reaction and biochemical tests. (Cowan and Steel, 1993).

\section{Assay for antimicrobial activity.}

Antimicrobial activities of extracts were determined by the agar well diffusion method (Schinor et al., 2007). A 0.2 $\mathrm{ml}$ of a $24 \mathrm{~h}$ broth culture was aseptically introduced into the sterile Petri dishes. The sterilized medium at $45-50^{\circ} \mathrm{C}$ was poured into Petri dishes. The agar depth was $4 \mathrm{~mm}$. $25 \mathrm{ml}$ medium was used for plates with $90 \mathrm{~mm}$ diameter. Wells were made on the agar plates using a sterile cork borer of $5 \mathrm{~mm}$ diameter. A $0.5 \mathrm{ml}$ of each extract was pipette into the well. A negative control was $0.01 \mathrm{ml}$ of the extracting solvent. The plates were allowed on the bench for 40 minutes for pre diffusion of the extract to occur. The treated Petri dishes were incubated overnight at $37^{\circ}$ $\mathrm{C}$ for $24 \mathrm{~h}$.

\section{Phytochemical screening}

Chemical tests were carried out on the aqueous extracts to identify the constituents using standard procedures
(Harborne, 1973; Trease and Evans, 1989; Sofowora, 1993).

\section{Preparation of sample.}

Two grams of each extract was carefully weighed into $250 \mathrm{ml}$ conical flask and $50 \mathrm{ml}$ of distilled water was added to it. It was mixed and stopper with rubber bung, then incubated in water bath for $2 \mathrm{~h}$ at $37^{\circ} \mathrm{C}$, and then allowed to cool. The content was filtrated with the use of Whatman filter paper No 1 and the filtrate was kept for analysis.

\section{Test for saponins}

$5 \mathrm{ml}$ of aqueous extract was shaken vigorously with $5 \mathrm{ml}$ of distilled water in a test tube and warmed. The formation of stable foam was taken as an indication for the presence of saponins.

\section{Test for Alkaloids}

To 0.5 gram of the extracts in a test tube was added $5 \mathrm{ml}$ of $10 \%(\mathrm{v} / \mathrm{v}) \mathrm{HCL}$ and put in a stream bath for 2 minutes, after which the mixture was filtrated. To separate portions, $1 \mathrm{ml}$ of the filtrate was added followed by 3 drops of dragendroff reagent. The presence of alkaloids was confirmed by the production of reddish-brown.

\section{Test for Tannin}

Ten $\mathrm{ml}$ from the filtrates was taken into $100 \mathrm{ml}$ volumetric flask. $15 \mathrm{ml}$ Folin Denis reagent and $10 \mathrm{ml}$ of $\mathrm{Na}_{2} \mathrm{CO}_{3}$ solution was diluted with distilled water, mixed well and the absorption were read after 30 minutes at $760 \mathrm{~nm}$.

\section{Test for flavonoids}

To $1 \mathrm{ml}$ of aqueous extract was added $1 \mathrm{ml}$ of $10 \%$ lead acetate solution. The formation of a yellow precipitate was taken as a positive test for flavonoid.

\section{Test for phlobatannins}

About $2 \mathrm{ml}$ of aqueous extract was added to $2 \mathrm{ml}$ of $1 \%$ $\mathrm{HCl}$ and the mixture was boiled. Deposition of a red precipitate was taken as an evidence for the presence of phlobatannin

\section{Tests for anthraquinones}

To $3 \mathrm{ml}$ of aqueous extract was shaken with $3 \mathrm{ml}$ of benzene, filtered and $5 \mathrm{ml}$ of $10 \%$ ammonia solution was added to the filtrate. The mixture was shaken and the 
004 Afr. J. Food Sci. Technol.

Table 1. Aerobic Microflora isolated from meat

\begin{tabular}{lr}
\hline Isolate & Identity \\
\hline 1 & Serratia marcescens \\
2 & Micrococcus luteus \\
3 & Streptococcus pyrogens \\
4 & Pseudomonas aeruginosa \\
5 & Bacillus cereus \\
\hline
\end{tabular}

presence of a pink, red or violet colour in the ammonical (lower) phase indicates the presence of free anthraquinones.

\section{Tests for glycosides}

\section{Liebermann's test:}

To $2 \mathrm{ml}$ of the organic extract was dissolved in $2 \mathrm{ml}$ of chloroform and $2 \mathrm{ml}$ of acetic acid was added and the solution cooled well in ice. Sulphuric acid was then added carefully. A colour change from violet to blue to green indicates the presence of a steroidal nucleus (that is, a glycone portion of glycoside).

\section{Salkowski's test:}

To $2 \mathrm{ml}$ of each extract was dissolved in $2 \mathrm{ml}$ of chloroform. $2 \mathrm{ml}$ of sulphuric acid was added carefully and shaken gently. A reddish brown colour indicates the presence of a steriodal ring (that is, a glycone portion of glycoside).

\section{Keller-Killiani Test}

Exactly 0.5 gram of extracts were dissolved in $2.0 \mathrm{ml}$ glacial acetic acid containing one drop of ferric chloride solution this was under laid with $0.1 \mathrm{ml}$ of concentrated sulphuric acid. A brown ring obtained at the inter face indicated the presence of deoxysugar, a characteristics of cardenolides. A violet ring may appear below the brown ring while the acetic acid layer, a greenish ring may form just above the ring and gradually speed throughout this layer.

\section{Total phenol}

The phenolic content was determined according to the method described by Spanos with slight modifications (Spanos and Wrolstad, 1990). The assay was determined using $1 \mathrm{~mL}$ of each extract stock solution $\left(1 \mathrm{mg} \mathrm{mL}^{-1}\right)$ and $1 \mathrm{~mL}$ of each standard gallic acid solution was taken in $25 \mathrm{~mL}$ volumetric flask, added $10 \mathrm{~mL}$ of water, $1.5 \mathrm{~mL}$ of Folin-Ciocalteu reagent and allowed to stand for 10 min then $4 \mathrm{~mL}$ of sodium carbonate solution was added in each volumetric flask and volume was adjusted with distilled water. Absorbance were measured after $1 \mathrm{~h}$ at $765 \mathrm{~nm}$ by UV visible spectrophotometer against blank.
The total phenolic content was calculated from the calibration curve of gallic acid and the results were expressed in $\mathrm{mg}$ gallic acid equivalent per gram of dried extract.

\section{Statistical Analysis}

All experiments were carried out in triplicate. Data obtained were analysed by one way analysis of variance and mean were compared by Duncan multiple range test (SPSS 18.0 version). Differences were considered significant at $P \leq 0.05$.

\section{RESULTS AND DISCUSSION}

\section{Identification}

Aerobic bacterial isolates obtained from the meat include Serratia marcescens, Micrococcus luteus, Streptococcus pyrogens, Pseudomonas aeruginosa and Bacillus cereus (Table 1). The microorganism found occur frequently on freshly cut and aerobically stored meat (Doulgeraki et al., 2012; Hultman et al., 2015). They are recongnised as undesirable bacteria in food processing environment (De Filippis et al., 2013; and Hultman et al., 2015) and as main contributors to meat spoilage (Moretro et al., 2013) . Most of the isolates above had been reported to be important spoilage organisms in meat (Lawrie and Ledward, 2006). Spoilage under aerobic conditions of raw meat causes surface slime which was attributed to Streptococcus pyrogens, Leuconostoc mesenteroids, Bacillus cereus and Micrococcus [frazer]. Earlier reports had implicated Pseudomonas one of isolates as being the predominant genera that are regularly found in meat at the beginning of storage. Pseudomonas was reportedly to be lipolytic and proteolytic, as were species belonging to the Enterobacteriaceae family, and they can contribute to spoilage through the production of volatile organic compound and other undesirable metabolites such as biogenic amines (Doulgeraki et al., 2012). The other microorganisms may be contaminants acquired as a result of posts laughtering operations.

\section{Assay for Antimicrobial}

The Ethanolic extract of Solanum lycopersicum var. cerasiforme exerted a concentration dependent inhibitory 
Table 2. Zone of inhibition ( $\mathrm{mm}$ ) of extract against aerobic microflora from meat.

\begin{tabular}{|c|c|c|c|c|c|c|}
\hline & UEE & $E$ & $\mathrm{CN}$ & S & SXT & AU \\
\hline $\begin{array}{l}\text { Serratia } \\
\text { Marcenses }\end{array}$ & $7.53 \pm 0.01^{a}$ & $\mathrm{NI}$ & $7.05 \pm 0.03^{c}$ & $3.27 \pm 0.03^{c}$ & $2.25 \pm 0.02^{d}$ & $5.28 \pm 0.01^{a}$ \\
\hline $\begin{array}{l}\text { Micrococcous } \\
\text { Luteus }\end{array}$ & $2.09 \pm 0.00^{d}$ & $\mathrm{NI}$ & $1.86 \pm 0.01^{\mathrm{e}}$ & $4.48 \pm 0.06^{b}$ & $3.31 \pm 0.07^{c}$ & $4.56 \pm 0.03^{c}$ \\
\hline $\begin{array}{l}\text { Streptococcus } \\
\text { Pyrogens }\end{array}$ & $6.46 \pm 0.02^{\mathrm{C}}$ & $2.48 \pm 0.02^{b}$ & $3.33 \pm 0.04^{d}$ & $2.23 \pm 0.04^{\mathrm{e}}$ & $5.41 \pm 0.01^{\mathrm{b}}$ & $\mathrm{NI}$ \\
\hline $\begin{array}{l}\text { Pseudomonas } \\
\text { aeruginosa }\end{array}$ & $\mathrm{NI}$ & $\mathrm{NI}$ & $9.67 \pm 0.00^{\mathrm{a}}$ & $5.19 \pm 0.01^{a}$ & $6.69 \pm 0.00^{\mathrm{a}}$ & $5.11 \pm 0.00^{b}$ \\
\hline Bacillus cereus & $6.64 \pm 0.02^{b}$ & $3.33 \pm 0.04^{a}$ & $7.23 \pm 0.03^{b}$ & $3.14 \pm 0.01^{d}$ & $1.32 \pm 0.04^{\mathrm{e}}$ & $\mathrm{NI}$ \\
\hline
\end{tabular}

Values are means SD of replicates $(n=3)$.

Keywords: NI-No inhibition, UEE: Ethanolic extract, E: Erythromycin, CN: Gentamycin, S: Streptomycin, SXT: Septrin, AU: Augmentin.

Table 3.Phytochemicals present in ethanolic extract of Solanum lycopersicum var. cerasiforme.

\begin{tabular}{lc}
\hline Phytochemical & UEE \\
\hline Saponin & $+\mathrm{ve}$ \\
Alkaloids & $+\mathrm{ve}$ \\
Tannin & $+\mathrm{ve}$ \\
Flavonoids & $+\mathrm{ve}$ \\
Phlobatannin & $+\mathrm{ve}$ \\
Anthraquinone & $-\mathrm{ve}$ \\
Cardiac glycosides & $+\mathrm{ve}$ \\
Liebermans & $+\mathrm{ve}$ \\
Salkowski & $+\mathrm{ve}$ \\
Keller Killians & $-\mathrm{ve}$ \\
Test & \\
\hline
\end{tabular}

Keywords: -ve: Not present, +ve: Present

Table 4. Percentage yield of ethanolic extract of Solanum lycopersicum var . cerasiforme

\begin{tabular}{lll}
\hline & $\%$ Yield & Total Phenol( $\left.{ }^{\star} \mathrm{TAE}\right)$ \\
\hline Solanum lycopersicum var. cerasiforme & $25.34 \pm 0.04$ & $22.12 \pm 0.01$ \\
\hline
\end{tabular}

Keywords: *TAE: Tannic acid equivalent. Values are means of replicates $(n=3)$.

effects on microbial isolates from meat. Inhibitory effect of UEE $(7.53 \pm 0.01 \mathrm{~mm})$ on Serratia marcescens was higher than all the commercial antibiotics used as positive control except gentamycin (Table 4). Presence of active alkaloids, flavonoids and high phenolic content in these extract may be the reason for good antibacterial activity. Phenolic compounds are known to have antimicrobial effects (Nychas et al., 2007). All the isolated organisms were resistant to erythromycin except Streptococcous pyrogens and Bacillus cereus. Pseudomonas species are recongnized as able to form biofilms. Additionally, chromosomal mutations (quinolone resistance due to mutation in DNA gyrase and topoisomerase IV gene) and lower membrane permeability for the antibiotics also contribute to antibiotic resistance (Lister et al., 2009). Resistance to antibiotics in foodborne pathogens may create problems for disease or illness treatment while antibiotic susceptibility leads to healing of the illness which the organisms caused.

The extract exhibited good antibacterial activity against spoilage organisms isolated from meat except Pseudomonas aeruginosa. The results obtained here also showed that Pseudomonas aeruginosa was susceptible to gentamycin, streptomycin, septrin and augmentin. The extract UEE had lowest inhibitory effect on Micrococcus luteus. Several studies also showed that phytochemicals can potentiate the activity of antibiotics in combination. The combinations of antibiotic sulfamethoxazole with protocatechuic acid/ellagic acid/gallic acid and tetracycline with gallic acid, cefoperazone with allicin showed synergistic mode of interaction and were highly effective in killing $P$. aeruginosa under in vitro conditions (Jayaraman et al., 2010) 
006 Afr. J. Food Sci. Technol.

\section{Phytochemicals}

Phytochemical screening of the extract revealed the presence of saponin, alkaloids, tannin, flavonoids phlobatannis anthraquinones and cardiac glycosides (Table 3). These are believed to be responsible for the observed antibacterial effects (Velioglu, 1998). Flavonoid derivatives were reported to be effective antimicrobial substances against different microorganisms. Their mode of activity may be due to their ability to complex with extracellular and soluble proteins as well as to complex with bacterial cell wall. The flavonoids being more lipophilic may also disrupt microbial membranes. In addition to being effective against bacteria, these compounds exhibit inhibitory effects against viruses and parasites (Cowan, 1999). It has been well established that flavonoids in nature are the potential antioxidants Saponins, which are amphipathic glycosides, may be mono- or polydesmodic, depending on the number of attached sugar moieties. These bio-active ingredients are commonly present in licorice root (Glycyrrhizaglabra), and possess expectorant, bacteriostatic and antiviral activities. (Cseke et al., 2006).

\section{CONCLUSION}

The results obtained from this study shows that the extract of these Solanum lycopersicum var. cerasiforme UEE, possess inhibitory potential against spoilage and pathogenic organisms that are associated with meat. cherry tomato has potential use in food preservation and enhancement of shelf life as a natural bioingredient. The bioactive components in this extract if further screened may serve as effective and safe alternatives to chemical preservatives which are known to have negative side effects. Isolation and identification of the specific bioactives responsible for inhibitory effect is the next research focus.

\section{REFERENCE}

Adams MR, Moss MO(2000). Food Microbiology. 2nd ed. Royal society of chemistry. London 193-202.

Aune D, Chan DS, Vieira AR, Rosenblatt DA, Vieira R, Greenwood DC Norat $\mathrm{T}(2012)$. Dietary compared with blood concentrations of carotenoids and breast cancer risk: A systematic review and metaanalysis of prospective. Am. J. Clin. Nutr. 356-373.

Aurand LW, Woods AT, Wells MR(1987). Meat and Meat product. In food composition and analysis. AVI publishing company New York. pp 596-597.

Cowan ST, Steel KJ(1993). Manual for Identification of medical bacteria. $3^{\text {rd }}$ edition. Cambridge University Press. Pp 40-50.

Cseke LJ, Kirakosyan A, Kaufman PB(2006). Natural Products from Plants (second ed.), CRC Press, Boca Raton, USA. p. 17.

De Filippis F, La Storia A, Villani F, Ercolini D(2013). Exploring the sources of bacterial spoilers in beefsteaks by culture-independent high-throughput sequencing. Plos One 8(7): e70222.doi:10.1371/journal.pone.0070222.
Doulgeraki Al, Ercolini D, Villani F, Nychas GJ(2012). Spoilage microbiota associated to the storage of raw meat in different conditions. Int J Food Microbio.I 157:130-41

Edward G(1999). Tomato consumption linked to lower cancer risk. J. natural cancer institute. 48(2):140-146.

Ellinger S, Ellinger J, Stehle $\mathrm{P}(2006)$. Tomatoes, tomato products and lycopene in the prevention and treatment of prostrate cancer. Journal Curr Opin Clin Nutr Metab Care. 9: 722-727.

Fawole MO, Oso BA(2001). Laboratory manual of Microbiology. 2nd ed. Spectrums Books Limited Ibadan, Nigeria. pp. 127.

Gill $\mathrm{CO}(2005)$. Sources of microbial contamination a slaughtering plants. In: Improving the safety of fresh meat, (J. N. Sofos, ed.), Cambridge, UK: CRC/Woodhead Publishing Limited. pp. 231-243.

Gill CO, Molin G(1991). Modified atmospheres and vacuum packaging, in Food Preservatives, (Russell, N.J., and Gould, G.W., eds), Blackie. Glasgow. pp. 172-99.

Harborne JB(1973). Phytochemical Methods. Chapman and Hall Ltd., London pp. 49-188.

Hultman J, Rahkila R, Ali J, Rousu J, Björkroth KJ(2015). Meat processing plant microbiome and contamination patterns of coldtolerant bacteria causing food safety and spoilage risks in the manufacture of vacuum-packaged cooked sausages. Appl. Environ. Microbiol. 81, 7088-7097. doi:10.1128/AEM.02228-15.

Jayaraman P, Sakharkar MK, Lim CS, Tang TH, Sakharkar KR (2010). Activity and interactions of antibiotic and phytochemical combinations against Pseudomonas aeruginosa in vitro Int. J. Biol. Sci., 6: 556-568.

Kalalou I, Faid M, Ahami AT(2004). Extending the shelf life of fresh minced camel meat at ambient temperature by Lactobacillus delbruekii subsp. delbruekii. Electronic J. Biotechnol. 7: 246-251.

Koutsoumanis KP, Sofos JN(2004). Microbial contamination of carcasses and cuts. In Encyclopedia of Meat Sci. (Jensens, W .K., Ed.). Amsterdam: Elsevier Academic Press. pp. 727-737.

Lambert AD, Smith JP, Dodds KL(1991). Shelf life extension and microbiological safety of fresh meat - A review. Food Microbiology 8 : 267-297

Lawrie RA, Ledward DA(2006). Lawrie meat science. 7th ed. Cambridge Woodhead publishing limited. Cambridge: England and CRC Press Boca Raton, New York, Washington DC. pp 75-155.

Lister PD, Wolter DJ, Hanson ND(2009). Antibacterial-resistant Pseudomonas aeruginosa: clinical impact and complex regulation of chromosomally encoded resistance mechanisms Clin. Microbiol. Rev., 22: 582-610.

Martinez-Valvercle MJ, Periage G, Provan A(2002). Chesson Phenolic compounds, Lycopene and antioxidant activities in commercial varieties of tomato (Lycopersicon esculentum). J. the Sci. of Food and Agric. 82. 323-330.

Møretrø T, Langsrud S, Heir E(2013). Bacteria on meat abattoir meat production process surfaces after sanitation: characterisation of survival properties of Listeria monocytogenes and the commensal bacterial flora. Adv. Microbiol., 3:255-264.

Nychas GJE, Marshall D, Sofos J(2007). Meat Poultry and Seafood In Food Microbiology Fundamentals and Frontiers $3^{\text {rd }}$ Edition, Eds Doyle, Beuchat and Montville ASM Press pp. 105-140.

Nychas GJE, Skandamis PN, Tassou CC, Koutsoumanis KP (2008). Meat spoilage during distribution. Meat Science 78:77-89.

Olaoye OA, Idowu OA(2010). Features and functional properties of lactic acid bacteria used as biological preservatives of meat processing: A review article. J. Agric. Technol. 6: 449-460.

Onilude AA, Sanni AI, Olaoye OA, Ogunbanwo ST(2002). Influence of lactic cultures on the quality attributes of tsire, a West African stick meat. World J. Microbiol Biotechnol. 18: 615-619.

Paulsen P, Smulders FJM(2003). Combining natural antimicrobial systems with other preservation techniques: the case of meat. In: Food preservation techniques (Zeuthen, $P$., and Bùgh-Sùrensen, L., eds.). Woodhead Publishing Ltd, Cambridge, England and CRC Press Boca Raton, New York, Washington DC. pp 71-85.

Schinor EC, Salvador MJ, Ito IZ, Dias DA(2007). Evaluation of the antimicrobial activity of crude extracts and isolated constituents from Chresta scapigera. Braz. J. Microbiol., 38:145-149. 
Shahidi F, McDonald J, Chandrasekara A, Zhong Y(2008).

Phytochemicals of foods, beverages and fruit vinegars: chemistry and health effects. Asia Pac J Clin Nutr. 2008;17:380-382.

Sofowora A(1993). Medicinal Plants and Traditional Medicine in Africa. Spectrum Books Ltd., Ibadan, Nigeria, pp. 191-289.
Spanos GA, Wrolstad RE(1990). Influence of processing and storage on the phenolic composition of Thompson Seedless grape juice. $J$. Agric. Food Chem., 38: 1565-1571.

Velioglu YS, Mazza GG, Gao L, Oomah BD(1998). Antioxidant activity and total phenolics in selected fruits, vegetables and grain products. J. Agric and Food chem.46:4113-4117. 